\title{
STENANTHIUM LEIMANTHOIDES AND S. DENSUM (MELANTHIACEAE) REVISITED, WITH THE DESCRIPTION OF TWO NEW SPECIES
}

\author{
Bruce A. Sorrie and Alan S. Weakley \\ University of North Carolina Herbarium (NCU) \\ North Carolina Botanical Garden \\ Campus Box 3280 \\ Chapel Hill, North Carolina 27599, U.S.A. \\ basorrie@gmail.com
}

ABSTRACT

\begin{abstract}
The genus Stenanthium, distributed through much of eastern United States, has previously been circumscribed with four species. Herbarium and field research on Stenanthium densum and S. leimanthoides (Melanthiaceae) support the recognition of two new segregate species, $\mathbf{S}$. macrum and S. tennesseense. Data are presented on morphology, phenology, habitat, and distribution of each of these four species. Selected specimen records, distribution maps, field photographs, and a key to these four species are provided.
\end{abstract}

\section{RESUMEN}

El género Stenanthium, distribuido por el este de los Estados Unidos, ha sido circunscrito previamente con cuatros especies. Investigaciones de Herbario y campo en Stenanthium densum y S. leimanthoides (Melanthiaceae) soportan el reconocimiento de la segregación de dos nuevas especies, S. macrum y S. tennesseense. Se presentan datos de su morfología, fenología, hábitat, y distribución de cada una de estas cuatro especies. Se aportan citas de especímenes seleccionados, mapas de distribución, fotografías de campo, y una clave de estas cuatro especies.

\section{INTRODUCTION}

Plants of Stenanthium leimanthoides (A. Gray) Zomlefer \& Judd (=Zigadenus leimanthoides A. Gray) have traditionally been identified by their branched racemose inflorescences compared to the simple racemes of $S$. densum (Desr.) Zomlefer \& Judd [= Z. densus (Desr.) Fern.] (Chapman 1897; Small 1933; Fernald 1950; Gleason 1952; Radford et al. 1968; Correll \& Johnston 1970; Zomlefer \& Judd 2002). Stenanthium leimanthoides inhabits shrub balds and boggy habitats in the southern Appalachian Mountains of West Virginia, Virginia, and North Carolina, and boggy or seepage habitats on the Coastal Plain of Delaware, New Jersey, and New York. The species was added to the flora of the Maryland Coastal Plain in 2007 (Knapp et al. 2011). Plants disjunct to central Tennessee, also with branched racemes, have traditionally been assigned to $S$. leimanthoides despite some morphological inconsistencies (Chester et al. 1993; Tennessee Flora Committee 2015).

Stenanthium densum has been recorded from wet savannas and seepage slopes on the Atlantic and Gulf Coastal Plain (i.e., no inland/upland populations), from Virginia south to Florida and Mississippi. However, during the twentieth century it became apparent that a significant number of populations from the Gulf Coastal Plain from Georgia to Texas bore branched racemes; accordingly, they were identified as S. leimanthoides (Anderson 1995; Carter et al. 2009; Morris 2012). Diggs et al. (2006) described the inflorescence of Gulf Coast S. densum (their concept included S. leimanthoides) as a raceme or panicle of racemes, and "while distinct in some areas, the two entities intergrade (size, inflorescence morphology, flowering time) in the Gulf Coast area." They posited that "Plant size, which is determined by age and environment, appears to affect inflorescence morphology—smaller plants tend to have simple racemes, while larger plants develop panicles"; a concept originally suggested by McDearman (1984, 1994). Schwartz (2002) also synonymized leimanthoides within densus in her treatment of Zigadenus for the Flora of North America.

However, all Stenanthium densum specimens seen from the Atlantic Coastal Plain possess simple racemes (i.e., no robust plants with branched racemes occur). This throws into question the true identity of the Gulf Coastal Plain panicled plants. Anderson (1995) recognized the large plants with branched inflorescences in northwestern Florida as distinct from S. densum. He stated that "The taxonomic relationships are complicated further because the type specimens of $Z$. leimanthoides are relatively small plants from the mountains of North Carolina, whereas plants from the Florida Coastal Plain are very robust (they may represent a separate taxon)." 
Carter et al. (2009) and Morris (2012) also recognized Gulf Coastal Plain S. leimanthoides as distinct from S. densum. In this paper we re-examine the identity of $S$. leimanthoides relative to $S$. densum.

\section{METHODS}

Field work by the senior author conducted in the 1990s and 2000s throughout the southern Atlantic Coastal Plain and the Gulf Coastal Plain provided data on morphology, habitat, and distribution of Stenanthium taxa and gave impetus to this study. Specimens of S. leimanthoides and S. densum were borrowed from BRIT, DUKE, FSU, GH, IBE, MISSA, NCU, TENN, and VDB. We contacted a number of botanists with field and herbarium knowledge of these taxa to fill in distribution gaps.

We assessed nine potential morphological characters: basal sheaths and their fibers, leaf width, inflorescence branching, pedicel bract shape and length, pedicel length, tepal length, and capsule length. For each character, 25 measurements or evaluations were made.

RESULTS

\section{Morphology}

One character considered to be useful in separating S. leimanthoides from S. densum is the basal gland on the tepals: "small" and "yellow" in S. leimanthoides and "obscure" in S. densum according to Gleason (1952); "with a deeper yellowish spot" in S. leimanthoides and "usually with a very small gland at base when fresh" in S. densum according to Fernald (1950). We observed that dried specimens of northern S. leimanthoides, and plants from central Tennessee, did indeed show a basal blotch of a darker hue than the rest of the tepal, and very slightly raised above the tepal surface. In living plants this blotch is pale yellow and indistinct. In contrast, we were unable to discern any glands at all in dried specimens or living plants of S. densum or Gulf Coast S. leimanthoides (pers. obs. and photographs). Pedicel length was eliminated from analysis after it became evident that length varied positively with age of the inflorescence or inflorescence branch (pers. obs.).

Table 1 displays characters that we found most informative in discriminating among the Stenanthium taxa under study. Basal sheath fibers are the remains of former leaf bases which remain loosely to tightly attached to the stem base. The color purple here is interpreted as "red-purple," not violet which has a much bluer tint. Leaf width measurements are of the widest blade of each plant. Pedicel bracts occur at the junction of the pedicel and the inflorescence rachis; we measured only bracts on the central rachis, not on branches. Capsule length includes the attenuate tip. "Northern leimanthoides" includes plants from lowlands of New York to Maryland and from the Appalachians of West Virginia to North Carolina. "Tennessee leimanthoides" includes plants from the Eastern Highland Rim and Cumberland Plateau of Tennessee. "Gulf Coast leimanthoides" includes plants from southern Georgia to eastern Texas. Stenanthium densum includes plants with unbranched inflorescences from the Coastal Plain of southeastern Virginia to central Florida and southeastern Mississippi.

The two major divisions in Table 1 are: "Northern leimanthoides"-"Tennessee leimanthoides" on the one hand, and "Gulf Coast leimanthoides"-"S. densum sensu stricto" on the other. Six characters serve to place each specimen into one division or the other. Basal sheath color, presence of basal sheath fibers, number of pedicels per centimeter of central raceme, tepal color post-anthesis, presence of tepal gland, and flowering dates cleanly distinguish between two groups of taxa. Thus, "Tennessee leimanthoides" aligns with "northern leimanthoides," differing in pedicel bract length and leaf width. Likewise, "Gulf Coast leimanthoides" aligns with S. densum, differing in larger size and in inflorescence branching.

Range disjunction (Fig. 1) coupled with morphological differences (in plant height, leaf width, and pedicel bract length) between the two northern taxa supports species level discrimination, as separate evolutionary entities based on morphology and biogeography.

The two Coastal Plain taxa differ in plant height, leaf width, and branched (vs. unbranched) inflorescences. In the field, the robust aspect of "Gulf Coast leimanthoides" is striking. However, this species occupies precisely the same seepage bog habitats (specimen label data and pers. obs.). The range maps of "Gulf Coast leimanthoides" (Fig. 2) and S. densum (Fig. 3) show that the former is in the minority in Georgia, but westward it becomes the majority in terms of numbers of populations and individuals, thus suggesting a gradual replacement distribution pattern. Curiously, branched inflorescences have been documented in Greensville County, 
TABLE 1. Character states of 1) Stenanthium leimanthoides from southern Appalachians plus Maryland to New York; 2) S. leimanthoides (branched inflorescences) from central Tennessee; 3) S. leimanthoides (branched inflorescences) from the Coastal Plain of Georgia and panhandle Florida west to Texas; 4) S. densum from the Coastal Plain of Virginia to peninsular Florida and Mississippi. Measurements are in millimeters and $n=25$, unless otherwise stated.

\begin{tabular}{|c|c|c|c|c|}
\hline Character state & Northern "leimanthoides" & Tennessee "leimanthoides" & Gulf Coast "leimanthoides" & S. densum sensu stricto \\
\hline Basal sheath color & $\begin{array}{l}\text { Brown, occasionally } \\
\text { purplish brown }\end{array}$ & $\begin{array}{l}\text { Brown, occasionally } \\
\text { purplish brown }\end{array}$ & Purple & Purple \\
\hline Basal sheath fibers & $\begin{array}{l}\text { Densely clothed with } \\
\text { fibers (rare specimens } \\
\text { may be stripped of fibers } \\
\text { during collecting) }\end{array}$ & $\begin{array}{l}\text { Densely/moderately } \\
\text { clothed with fibers } \\
\text { (rare specimens may be } \\
\text { stripped of fibers } \\
\text { during collecting) }\end{array}$ & $\begin{array}{l}\text { Without fibers }(3 / 36 \\
\text { specimens have moderate } \\
\text { number of fibers) }\end{array}$ & $\begin{array}{l}\text { Without fibers }(5 / 120 \\
\text { specimens have sparse } \\
\text { to moderate fibers) }\end{array}$ \\
\hline $\begin{array}{l}\text { Width of largest } \\
\text { leaves, mean }\end{array}$ & 7.7 & 4.8 & 7.1 & 4.3 \\
\hline Plant height, mean & $71.6 \mathrm{~cm}$ & $87.8 \mathrm{~cm}$ & $114.6 \mathrm{~cm}$ & $67.8 \mathrm{~cm}$ \\
\hline $\begin{array}{l}\text { Inflorescence } \\
\text { branched }\end{array}$ & Yes & $\begin{array}{l}\text { Yes }(11 / 12 \text { specimens } \\
\text { branched) }\end{array}$ & Yes & $\begin{array}{l}\text { No }(1 / 120 \text { specimens } \\
\text { branched) }\end{array}$ \\
\hline $\begin{array}{l}\text { Number of pedicels } \\
\text { per } 5 \mathrm{~cm} \text { of central } \\
\text { raceme, mean }\end{array}$ & 32 & 32 & 42.5 & 44.5 \\
\hline $\begin{array}{l}\text { Pedicel bract shape } \\
\text { and length, mean }\end{array}$ & Attenuate, 4.5 & Attenuate to acute, 3.3 & Attenuate to acute, 3.7 & Acute, 3.2 \\
\hline $\begin{array}{l}\text { Tepal color post- } \\
\text { anthesis, living } \\
\text { plants }\end{array}$ & $\begin{array}{l}\text { Dull green or olive; no } \\
\text { purple tinge }\end{array}$ & $\begin{array}{l}\text { Dull green or olive; no } \\
\text { purple tinge }\end{array}$ & $\begin{array}{l}\text { Dull white with purple } \\
\text { tinge on margin or purple } \\
\text { tinged throughout }\end{array}$ & $\begin{array}{l}\text { Dull white with purple } \\
\text { tinge on margin or pur- } \\
\text { ple tinged throughout }\end{array}$ \\
\hline Tepal length, mean & 3.7 & 3.8 & 3.6 & 3.4 \\
\hline Tepal gland & Present & Present & Absent & Absent \\
\hline Capsule length & 9.6 & 10.4 & 13.3 & 11.0 \\
\hline Flowering dates & 22 Jun-5 Aug & 1 Jun-26 Jul & 15 Apr-9 Jun & 8 Mar-19 Jun \\
\hline
\end{tabular}

Virginia [Fernald and Moore 15078 (GH), the specimen otherwise with the dimensions of S. densum)], and unbranched inflorescences were reportedly found in Henderson and Tyler counties, Texas (MacRoberts et al. 1999)_suggesting that there may be incomplete genetic separation or developmental anomalies or variation that makes inflorescence branching a less than $100 \%$ effective character. It would be extremely useful to obtain data on potential interbreeding of these two taxa on the Gulf Coast. The senior author found mixed populations of both Coastal Plain entities at two sites in southern Mississippi (Jackson County, Sorrie 9153 NCU), one in southern Alabama (Mobile County, Sorrie 9159 NCU), and one in the panhandle of Florida during the course of field work in 1996-98. In one Mississippi population "intermediate" plants were seen; there was no obvious intergradation at the other sites (BAS, field notes). There is a critical need to voucher additional populations to determine the extent of intergradation between "Gulf Coast leimanthoides" and S. densum, and whether such intergradation is significant. Meanwhile, we prefer to recognize "Gulf Coast leimanthoides" at species level, as separate evolutionary entities with different but overlapping distributions, nearly always maintaining their separate morphological features even in their region of sympatry.

Phenology.-Table 1 shows a nearly non-overlapping range of flowering dates between the two northern/ inland taxa and the two Coastal Plain taxa. Even allowing for differences in length of growing season, there is a striking difference in timing of the former taxa (late) vs. the latter (early).

Taxonomy.-The following taxonomic treatment includes four species of Stenanthium, based on modern evolutionary species concepts. We assert that the four entities here recognized are each separately evolving evolutionary lineages, based on multiple fields of evidence: they are phenetically distinguishable based on multiple characters, diagnosable, ecologically and biogeographically distinct, and largely or completely reproductively isolated from one another by phenology and other factors (de Quieroz 2007). 


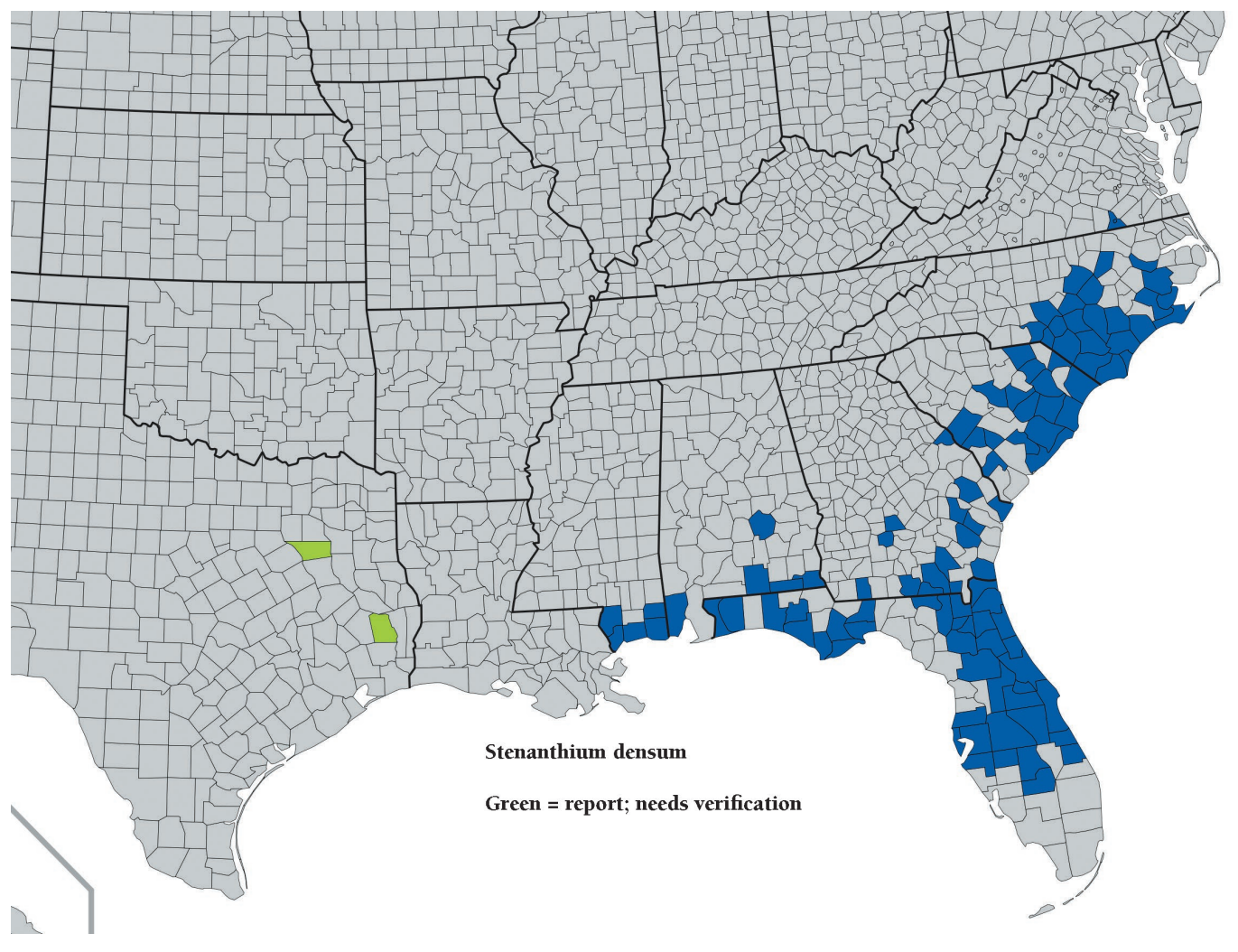

FIG. 1. Known distribution of Stenanthium densum, based on herbarium records.

Stenanthium leimanthoides (A. Gray) Zomlefer \& Judd. (Fig. 4). See Zomlefer \& Judd (2002) for publication data of basionym and lectotype.

Selected specimens examined. DELAWARE. New Castle Co.: 2 mi W of Wilmington, M. Crane's swamp, 11 Jul 1866, Commons s.n. (GH). MARYLAND. Cecil Co.: NE of Belvedere 0.8 km, freshwater seepage underlain by terraced gravel deposits, 4 Aug 2009, Knapp et al. 2968 (FLAS, US). NEW JERSEY. Burlington Co.: low ground, 3 Jul 1866, Parker s.n. (F). Camden Co.: prope Haddonfield, 20 Jul 1837, Durand s.n. (GH, NY). Monmouth Co.: meadows near Shark River, 22 Aug 1854, Hexamer s.n. (GH). NEW YORK. Nassau Co.: Bicknell s.n. (NY). NORTH CAROLINA: Avery Co.: Grandfather Mountain, Sept 1843, Gray s.n. (GH); sheltered niches along ridgelike summit of Grandfather Mountain, elev. ca. $6000 \mathrm{ft}$, perianth becoming green and functional after anthesis, Jul 1953, Barrell s.n. (GH); dry rocky soil, thicket on mountainside 2 mi NE of Linville, 5 Aug 1922, Randolph \& Randolph 1203 (GH); Burke Co.: Table Mountain, 1835, Curtis s.n. (GH, NY). Yancey Co.: Mount Mitchell State Park, Commissary Ridge on old railroad grade, elev. 5800 ft, 25 Jul 1971, McLeod 1375 (NCU). PENNSYLVANIA. [no county]: near Philadelphia, 22 Jun 1889, Greenman 1250 (GH). VIRGINIA. Grayson Co.: Big Spring Bog, 26 Jul 1981, S. EM. Bentley s.n. (FARM). WEST VIRGINIA. Grant Co.: Dolly Sods, top of the mountain, growing with sphagnum moss in wet bog, 6 Aug 1977, Farley s.n. (MUHW). Randolph Co.: open riverbank, Shavers Fork below Cheat Bridge, 26 Jul 1997, Grafton s.n. (MUHW). Tucker Co.: Bear Rocks area of Dolly Sods, windswept plateau, 5 Aug 1995, Suiter s.n. (MUHW).

Stenanthium tennesseense Sorrie \& Weakley, sp. nov. (Fig. 5). TYPE: TENNESSEE. Grundy Co.: boggy meadow between Tracey City and Coalmont, 3 Aug 1947, R.E. Shanks, A.J. Sharp, and E. Clebsch 5203 (hoLotype: TENN!).

Similar to S. leimanthoides, but plants taller (mean $87.8 \mathrm{~mm}$ vs. $71.6 \mathrm{~mm}$ ), leaves narrower (mean $4.8 \mathrm{~mm}$ vs. $7.7 \mathrm{~mm}$ ), pedicel bracts shorter (mean $3.3 \mathrm{~mm}$ vs. $4.5 \mathrm{~mm}$ ), and capsules longer (mean $10.4 \mathrm{~mm}$ vs. $9.6 \mathrm{~mm}$ ).

Description. Perennial herb from a bulbous base, fibers from old leaf bases dense to moderately dense. Basal sheath brown (occasionally purplish brown). Leaves basal and near-basal, the few distal leaves much reduced; basal leaves 3-7 mm wide (mean 4.8) and up to $50 \mathrm{~cm}$ long. Stem simple, 65-108 cm tall (mean 87.8). Inflorescence a panicled raceme, branches 1 -several. Tepals $6, \pm$ elliptic, 3.0-4.0 mm long, white, fading 


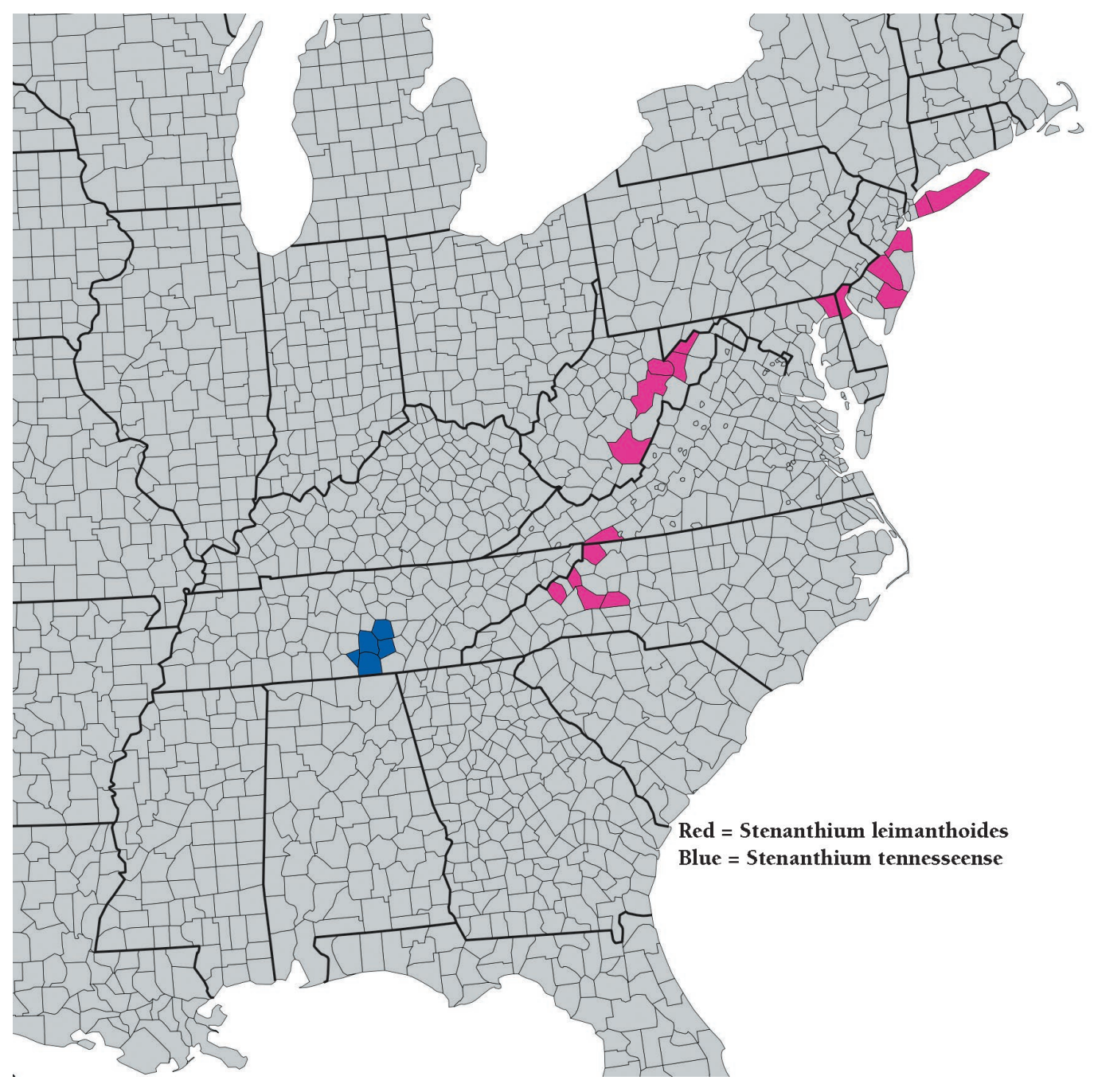

FIG. 2. Distribution of Stenanthium leimanthoides (red) and Stenanthium tennesseense (blue).

greenish post-anthesis. Tepal gland basal, very slightly raised, yellowish. Capsules narrowly conic, 8-13 mm long, (mean 10.4), greenish to brownish.

Selected specimens examined. TENNESSEE. Coffee Co.: open grassy swamps, oak barrens E of Tullahoma, 24 Jun 1938, Svenson 9683 (BRIT, GH); Tullahoma, 10 Jul 1886, Gattinger s.n. (DUKE, F, NY); SE of Manchester, 3 Aug 1947, Sharp and Shanks 5276 (TENN); just N of Manchester by I-24, 21 Jun 1974, Kral 53219 (NY); peaty powerline just W of Arnold Space Center HQ, 6 Jun 1989, Kral 76578 (VDB); wet open area under powerline near Gate 3, Arnold Engineering Development Center, 10 Jun 1980, Horn 7 (VDB); Arnold Engineering Development Center, under powerline on access road 3 mi, W of main gate, 1 Jun 1992, DeSelm s.n. (TENN); Arnold Engineering Development Center, roadside wet barrens on hwy. 55 between Manchester and Tullahoma, several hundred flowering stems, 18 Jun 1993 , Pyne 93-132 (MO); low places in oak barrens just N of Manchester, 21 Jun 1974, Kral 53219 (VDB); sandy peaty clearings in low oak barrens 1 mi. N of Tullahoma, 2 Jun 1982, Kral 68708 (VDB); May Prairie State Natural Area, Hillsboro Road, mesic oak barrens, 25 Jun 1997, Pyne 97-025 (APSC, NCU). Franklin Co.: Carter Mountain, remnant of swamp in clear-cut 0.8 mi from Rowe Gap Church, 1 Jul 1987, Jones 4995 (EKY, TENN); same place 4Jun 1987, Jones 4840 (VDB). Grundy Co.: swamp on N rim of Savage Gulf, Savage Gulf Natural Area, 26 Jul 1977, Wofford \& Webb 77-223 (TENN); Savage Gulf, swamp on north rim, 13 Jun 1979, Eagar \& Nossi s.n. (VDB); boggy meadow between Tracey City and Coalmont, 3 Aug 1947, Shanks, Sharp, and Clebsch 5203 (holotype, TENN); peat of swale in oak-pine, 5 mi. W of Altamont, 12 Jun 1991, Kral 78911 (VDB).. Moore Co.: SW of Tullahoma, Cumberland Springs WMA, growing in barrens along highway 130, 31 Jul 2002, 


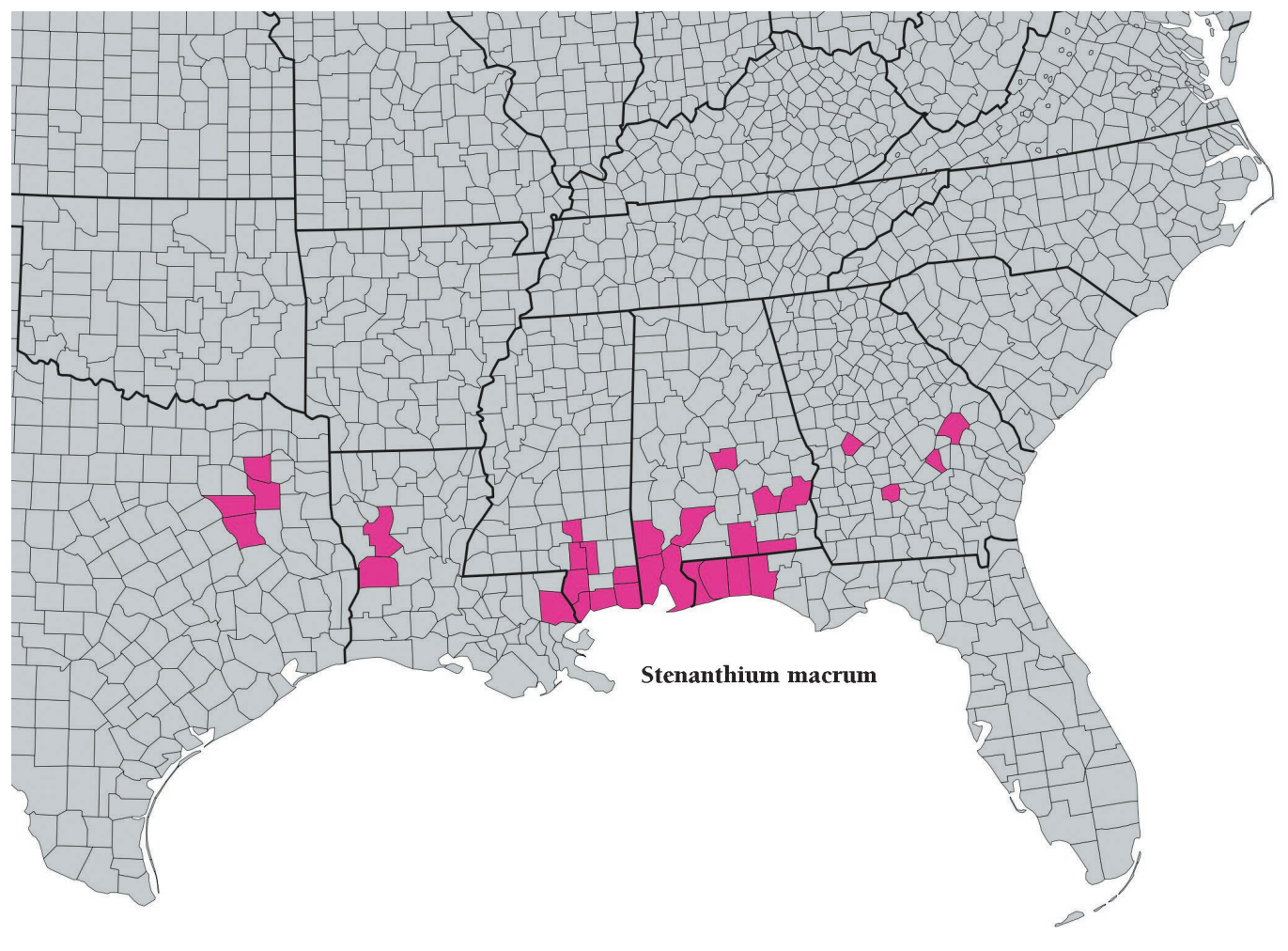

FIG. 3. Known distribution of Stenanthium macrum.

Estes 03806 (TENN); 4 mi W of Tullahoma, swampy places in woods, 5 Jun 1936, McVaugh 4447 (GA). Warren Co.: low wet area along route 55, just N of Morrison, 10 Jun 1999, Rhinehart s.n. (TENN).

Etymology.-The species is endemic to Tennessee.

Conservation.-Stenanthium tennesseense should be of conservation concern, as it only occurs in five counties, four with current or recent records and Grundy with historical records only. There are only 20 known collections, suggesting that $S$. tennesseense warrants a status survey to assess its population status.

Stenanthium densum (Desr.) Zomlefer $\&$ Judd. (Fig. 6). See Zomlefer \& Judd (2002) for publication data of basionym and holotype.

Selected specimens examined. ALABAMA. Covington Co.: Conecuh National Forest, Bass Road, pitcher plant bog, 9 May 2014, Diamond 25079 (TROY). Houston Co.: (TENN). Mobile Co.: May 1845, Sullivant s.n. (GH). FLORIDA. Franklin Co.: 11.8 mi E of Carrabelle Beach on U.S. 98, 20 Apr 1991, Mears s.n. (FLAS). Hardee Co.: 3 mi S of Zolfo Spring along railroad track, 24 Apr 1980, Wunderlin, Hansen, E Semple 8607 (FLAS). Hillsborough Co.: Hulsey Meadow, formerly open wet pineland, burned over and cleared, 16 Apr 1966, Lakela 29566 (NCU). Lake Co.: roadside of hwy. 98 between Lakeland and Dade City, 3 Apr 1970, Wofford 10403 (TENN). Nassau Co.: along route 200 about 17 mi SW of Callahan, 7 Apr 1962, Will, Jr. s.n. (NCU). GEORGIA: Camden Co.: exposed roadside along route 252 about 4 mi W of White Oak, 18 Apr 2001, McNeilus 01-63 (TENN). Echols Co.: low exposed area along route 94 about 3 mi W of Clinch County line, 22 Aug 1993 , McNeilus 93-1907 (TENN). Richmond Co.: Olney s.n. (GH). Wilcox Co.: low moist savanna between US 280 and railroad, 3.6 mi W of Rochelle, 3 Jul 1960, Browne, Jr. 2553 (NCU). MISSISSIPPI. Hancock Co.: about 5 mi NE of Santa Rosa, low wet flatwoods, 26 Apr 1981, McDaniel 24974 (TENN). Jackson Co.: Pecan, route 90 near Alabama state line, 16 Apr 1988, Hill 19127 (GH); Mississippi Sandhill Crane National Wildlife Refuge, wet savanna just N of old headquarters, 30\% of plants with branched inflorescences,16 Apr 1997, Sorrie 9153 (NCU). NORTH CAROLINA. Brunswick Co.: upland bog-clearing, 14 mi N of Southport, Orton Plantation, 17 May 1941, Godfrey, Pl. Exs. Gr. 1123 (GH, TENN). Carteret Co.: Croatan National Forest, savannah, Millis Road, 23 May 1978, Dorr 1461 (NCU). Moore Co.: Southern Pines, 12 Jun 1920, Becquaert 3534 (GH). Wake Co.: Mitchell's Mill, eastern part of Wake County, 29 Sep 1932, Coker \& Totten s.n. (NCU). SOUTH CAROLINA. [no county], "cette espece croit dans las lieux plus eleves et moins humides, Basse Caroline," Michaux s.n. (GH photo 


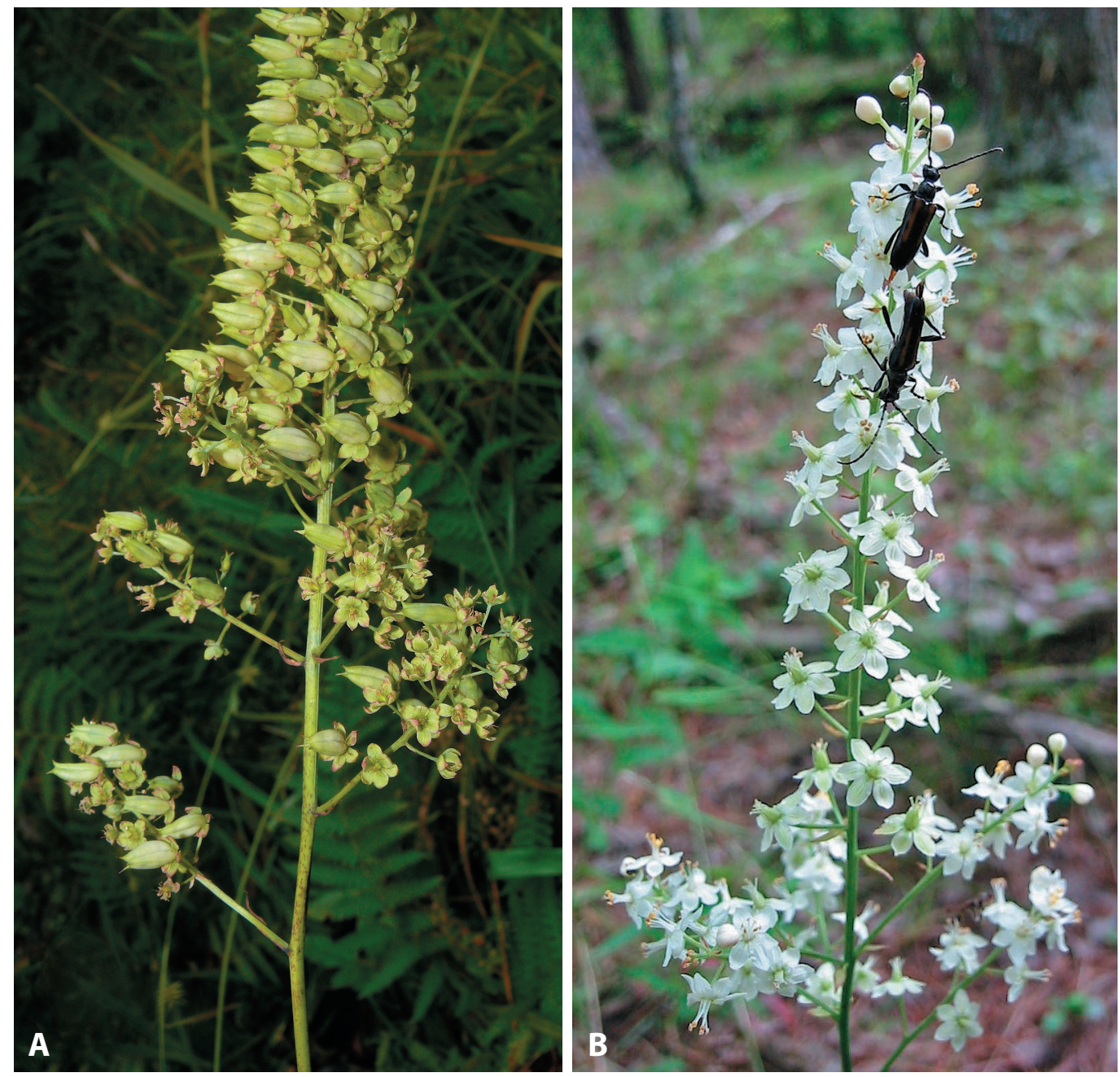

FIG. 4. Stenanthium leimanthoides. A. Cecil Co., Maryland. Photo W. Knapp. Note that corollas fade to greenish color. B. Grayson Co., Virginia. Photo Wilson.

of specimen at P). Beaufort Co.: sandy field, Beaufort, 26 Apr 1917, Churchill s.n. (GH). Charleston Co.: sold by Negroes in market under name of "Black Snakeroot," Robinson s.n. (GH). Williamsburg Co.: Savannah near US 521, 3 mi NW of Greeleyville, 21 Apr 1957, Radford 21273 (NCU). VIRGINIA. Greensville Co.: sphagnous bog about 1 mi NW of Dahlia, 7 Jun 1946, Fernald \& Moore 15078 (GH) [specimens show branched and unbranched inflorescences].

Stenanthium macrum Sorrie \& Weakley, sp. nov. (Figs. 3, 7). TYye: ALABAMA. MoвiLE Co.: S of Theodore in sunny moist field, common locally with Dichromena latifolia and Calopogon tuberosus, 1 May 1965, R. Deramus 420 (ноцотүPE: NCU!; ISOTYPES: IBE!, VDB!).

Similar to $S$. densum, but plants much taller (mean height $115 \mathrm{~cm}$ vs. $68 \mathrm{~cm}$ ), leaves much broader (mean width of largest leaves $7.1 \mathrm{~mm}$ vs. $4.3 \mathrm{~mm}$ ) and inflorescence branched (vs. unbranched).

Description. Perennial herb from a bulbous base, lacking fibers from old leaf bases (rarely possessing moderate numbers of fibers). Basal sheath purple. Leaves basal and near-basal, the few distal leaves much reduced; basal leaves 5-12 mm wide (mean 7.1) and up to $50 \mathrm{~cm}$ long. Stem simple, $70-155 \mathrm{~cm}$ tall (mean 115). Inflorescence a panicled raceme, branches 1-several. Tepals $6, \pm$ elliptic, $3.0-4.4 \mathrm{~mm}$ long, white, fading purplish post-anthesis. Tepal gland absent. Capsules slender-conic, 11-16 mm long (mean 13.3), purplish to brownish. 


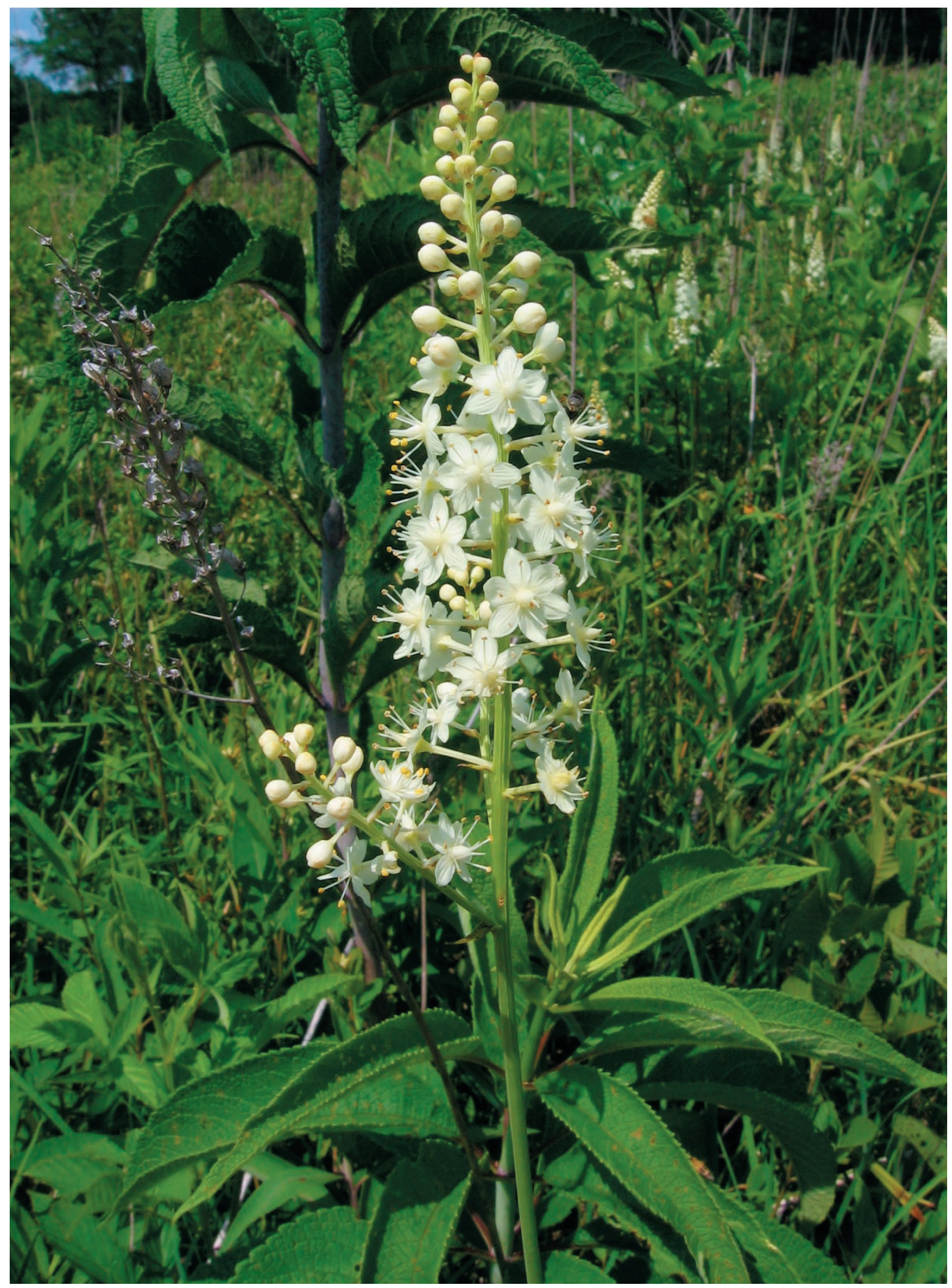

FIG. 5. Stenanthium tennesseense. Coffee Co., Tennessee. Photo M. Pyne. 

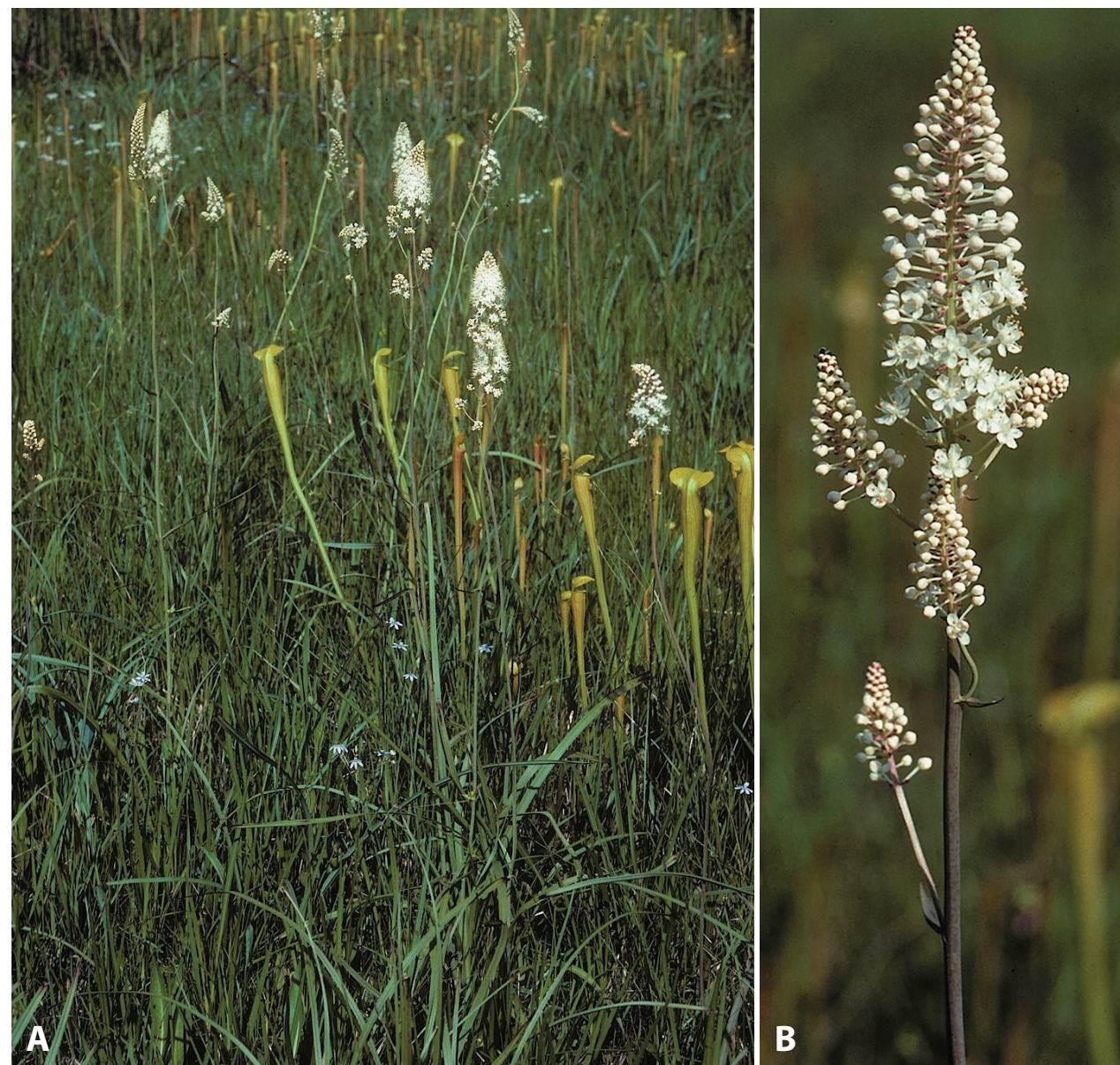

Fig. 6. Stenanthium macrum. A \& B. Jackson Co., Mississippi. Photos B. Sorrie.

Selected specimens examined. ALABAMA. Autauga Co.: M. \& O. railroad right-of-way in bottoms of Bridge Creek, 9 Jun 1927, Harper s.n. (GH). Baldwin Co.: mesic roadside, 3 mi N of Gulf Shores on hwy. 59, 14 May 1971, Evans 45982 (TENN). Barbour Co.: 30 May 2008, Morris s.n. (TROY). Covington Co.: low moist roadside just N of Mount Olive, 10 May 1967, Jones, Jr. 12266 (BRIT, FSU). Geneva Co.: 6 mi S of Ganer, savannah bog and swales in sandhills, 4Jun 1972, Kral 47183 (VDB). Mobile Co.: 7.5 mi S of Theodore in sunny moist field, common locally with Dichromena latifolia and Calopogon tuberosus, 1 May 1965, Deramus 420 (holotype NCU; isotypes IBE, VDB). Monroe Co.: bottoms ca. 4 mi S of Monroeville off US 84, 3 May 1972, Kral 46271 (FSU,GH, VDB). Pike Co.: sandy peat of pineland creek swale by route 10, $3.4 \mathrm{mi}$ NW of Clio, 7 Jun 1976, Kral 58189 (VDB). Washington Co.: ca. $1.5 \mathrm{mi} \mathrm{N}$ of Wagarville, sandy peat of pineland bog, 1 Jun 1972, Kral 47056 (AUA, VDB). FLORIDA. Escambia Co.: along creek S of Nine Mile Road, W of Pensacola, 27 May 1984, Burkhalter 9390 (FLAS, FSU). Okaloosa Co.: Eglin Air Force Base, sunny seepage slope under power line along Turkey Creek, 9 Jun 1994, Anderson 14944 (FSU). Walton Co.: shaded baygall bordering seepage slope, Blount Mill Creek drainage, 29 Jul 1994, Anderson 15140 (FSU). GEORGIA. Emanuel Co.: springy place in sandhills, Fifteen Mile Creek, 3 Jul 1901, Harper 989 (GH). Taylor Co.: 1876, Neisler s.n. (GH). Turner Co.: along branch swamp 5.1 mi ENE of Ashburn, 1970, Faircloth 6714 (GA, NCU). LOUISIANA. Natchitoches Par.: Kisatchie National Forest, large clearcut N of FS 366, E of Kisatchie Bayou Camp, 9 Jul 1988, Thomas 105524 (EKY, NLU). St. Tammany Par.: Money Hill TNC preserve, 27 Apr 2002, Tran \& Urbatsch 8 (LSU). Vernon Par.: Kisatchie National Forest, pitcher plant bog, MacRoberts \& MacRoberts 1646 (VDB). MISSISSIPPI. Covington Co.: low moist roadside just N of Mount Olive, 10 May 1967, Jones, Jr. \& Reynolds 12266 (MISS). Forrest Co.: Camp Shelby Training Site, abundant in long curving depression with Sarracenia alata, W side Poplar Creek, 1 Jun 2006, Leonard 12275 (NCU). George Co.: Sarracenia bog, Lucedale, 16 May 1954, Demaree 35202 (GH). Hancock Co.: Dead Tiger Savanna, common, 12 May 1984, McDaniel 27693 (IBE). Harrison Co.: Landon, boggy pine barrens, 7 April 1913, Lowe s.n. (MISSA). Jackson Co.: pitcher plant bog 3 mi S of George Co. line on rte. 57, 24 Apr 1965, Pullen 6527 (NCU). Lamar Co.: 2.5 mi S of Purvis, low area near longleaf pine woods, 6 May 1962, McDaniel 


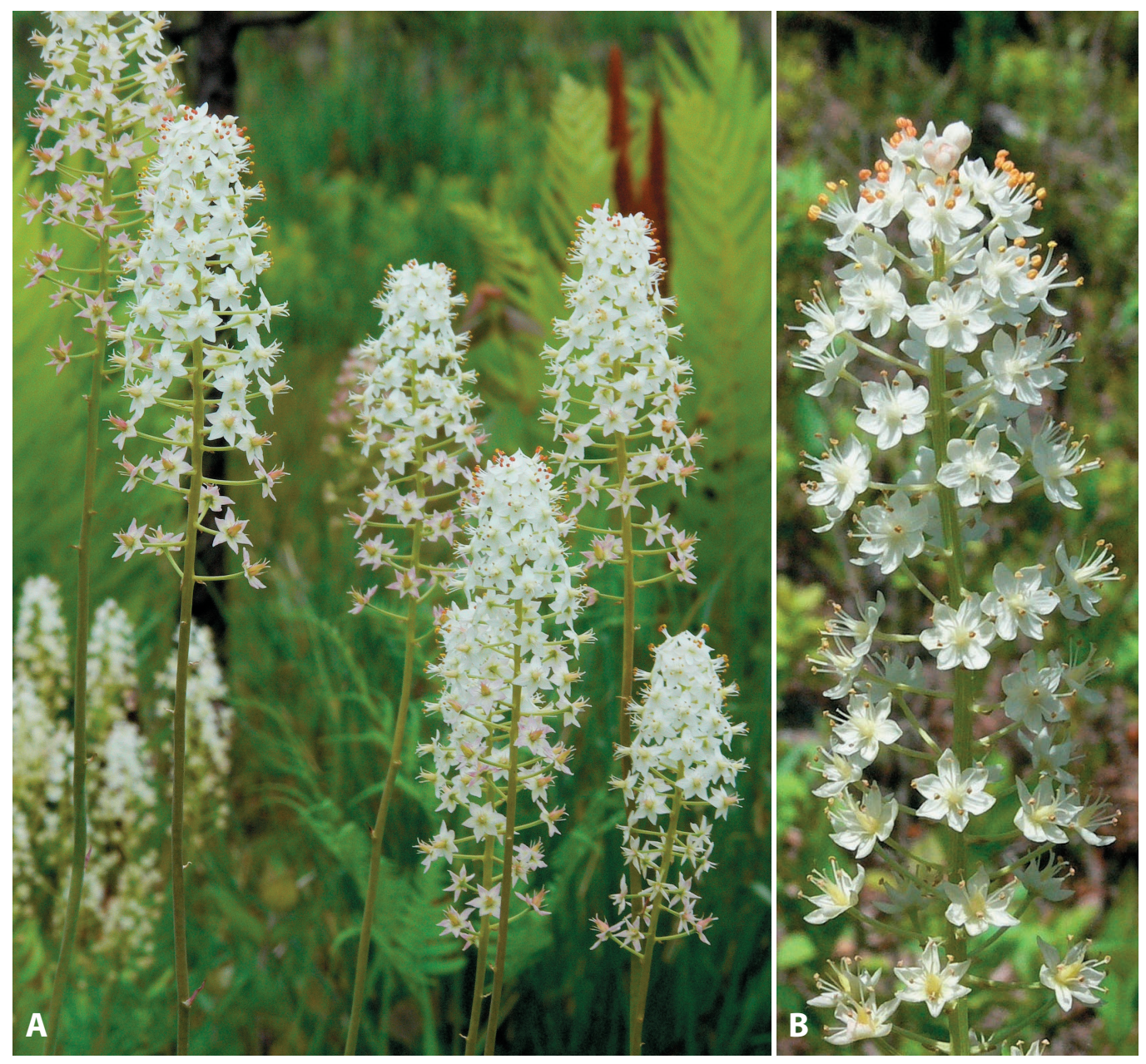

FIG. 7. Stenanthium densum. A \& B. Hoke Co., North Carolina. Photos B. Sorrie. In 7a, note that corollas fade to purplish color.

3136a (IBE). Pearl River Co.: low pine woods, I-59 just S of Lumberton exit, 3 May 1967, Jones, Jr. 11980 (NCU). TEXAS. Anderson Co.: Gus Engeling Wildlife Management Area, Andrew's pitcher plant bog, 3 May 1998, MacRoberts \& MacRoberts 3820 (LSUS). Henderson Co.: Bridges \& Orzell 7180 (BRIT). Smith Co.: Swan, swamps, 16 May 1902, Reverchon 2772 (GH, MO). Wood Co.: "specimen from Highway Flower Show, McKinney," 17 May 1940, Stillwell s.n. (BRIT).

Etymology.-The epithet macrum refers to the tall plant height and large leaves. The plants are among the tallest spring-flowering herbs in Gulf Coast seepage bogs (see Figure 6a where they tower over Sarracenia alata (Wood) Wood).

Conservation.-Stenanthium macrum is widespread and has no real threats.

The following key will distinguish the four species of Stenanthium here recognized.

1. Basal sheaths brown (occasionally purple tinged), densely to moderately clothed with remnant fibers; inflorescence branched; number of pedicels per $5 \mathrm{~cm}$ of raceme 22-50 (mean 32); tepals fade to dull green or olive on living plants; summer-flowering (mainly Jun-Jul); southern Appalachian Mountains and on lowlands of New York-New Jersey-DelawareMaryland, and disjunct in central Tennessee.

2. Pedicel bracts 3-6.5 mm long (mean 4.5) long; largest leaves 3-11 mm wide (mean 7.7); southern Appalachian Mountains and northern Atlantic Coastal Plain S. leimanthoides 2. Pedicel bracts 2.5-5.5 mm long (mean 3.3) long; largest leaves $2.5-7 \mathrm{~mm}$ wide (mean 4.8); central Tennessee 
1. Basal sheaths purple, fibers absent (occasionally sparse, rarely moderate); inflorescence unbranched or branched; tepals fade to purple on living plants; spring flowering (mostly Mar-May); southern Atlantic and Gulf Coastal Plain, from southeastern Virginia south to peninsular Florida and west to eastern Texas.

3. Plants short (mean $68 \mathrm{~cm}$ ); largest leaves 3-5(-7) mm wide (mean 4.3); inflorescence simple; southern Atlantic Coastal Plain and East Gulf Coastal Plain, southeastern Virginia south to peninsular Florida, west to southern Mississippi

3. Plants tall (mean $115 \mathrm{~cm}$ ); largest leaves 4-10(-12) mm wide (mean 7.1); inflorescence branched (rarely simple); East Gulf Coastal Plain and West Gulf Coastal Plain, from Georgia to eastern Texas

DISCUSSION

Distribution Patterns.-Distribution patterns of the four species examined in this study have strong parallels among other plant taxa. First, many species endemic to the Coastal Plain exhibit a distribution similar to that of S. densum (Sorrie \& Weakley 2001). For example, Bulbostylis ciliatifolia (Ell.) Fern. var. ciliatifolia, which ranges from southeastern Virginia to southern Mississippi; Eupatorium linearifolium Walt., which ranges from southeastern Virginia to southern Louisiana; Calopogon pallidus Chapm., which ranges from southeastern Virginia to southeastern Louisiana; and Digitaria serotina (Walt.) Michx., which ranges from southeastern Virginia to southern Alabama.

Second, the disjunction within S. leimanthoides sensu stricto-from the Coastal Plain of the northeastern states to the southern Appalachian Mountains-is a documented phytogeographic pattern, matched by Helonias bullata L., Xerophyllum asphodeloides (L.) Nutt., and nearly matched by Juncus caesariensis Coville and Kalmia buxifolia (Berg.) Gift, Kron, \& Stevens (Sorrie \& Weakley 2001).

Third, the disjunction shown between S. leimanthoides and S. tennesseense-from the southern Appalachians to central Tennessee-is apparently uncommon but has been documented for several species. As examples we cite Glyceria acutiflora Torr. and Vaccinium macrocarpon Ait., both of which have a northeastern range which extends down the Appalachians, thence disjunct to central Tennessee (Pyne 2000).

Species Biology.-McDearman $(1984,1994)$ postulated that branched inflorescences in Stenanthium leimanthoides sensu lato result from a developmental delay as compared with simple racemes of S. densum. He stated: "In the mountains and northern Atlantic Coastal Plain, the first reproductive episode occurs in plants at larger size classes, resulting in a compound raceme (delayed reproduction). Southward on the Coastal Plain to west Florida, the onset of reproduction occurs at smaller size classes, associated with a single terminal raceme, and plants do not appear to attain sizes for reproductive effort to result in a compound raceme [i.e., S. densum sensu stricto]. Further westward from west Florida to Louisiana, plants reproduce at small classes and grow and survive to larger classes, resulting in individuals producing simple as well as compound racemes" (McDearman 1994).

Based on observations of mixed populations on the Gulf Coastal Plain—some plants with simple inflorescences, others branched-McDearman reasoned that plant development and age may account for large individuals with branched inflorescences. "Plant size at the first episode of reproduction is small, with correspondingly small reproductive effort, resulting in fewer flowers arranged on a single terminal raceme. With increasing plant size (and age), absolute reproductive increases, number of flowers increases, and inflorescence morphology shifts from a simple terminal raceme to a compound raceme" (McDearman 1994).

However, we have not been able to corroborate the scenario put forth by McDearman. All montane and northern Atlantic Coastal Plain plants (S. leimanthoides sensu stricto) we have observed produce branched inflorescences over a wide range of plant height (range 47-109 cm) and leaf width (range 3.0-11.0 mm). We are unable to detect meaningful size classes. Plants of the southern Atlantic Coastal Plain, ranging west to southern Mississippi, produce only simple racemes (S. densum sensu stricto), with a range of plant height (range $36-85 \mathrm{~cm}$ ) and leaf width (range $2.0-8.0 \mathrm{~mm}$ ) and no discernable size classes.

We concur that there appear to be plants of intermediate size between S. macrum and S. densum; however, to date they have been found only very locally at a few sites in Florida and Mississippi. The vast majority of populations of $S$. densum and S. macrum maintain their morphological differences throughout the overlap zone of southern Georgia to southern Mississippi. 
In conclusion, our analyses point to a taxonomy based on morphology and biogeography, not on a developmental basis.

\section{ACKNOWLEDGMENTS}

We heartily acknowledge the staff of the following herbaria for loans or online records: AUA, BRIT, DUKE, EKY, FLAS, FSU, GA, GH, IBE, LSU, LSUS, MISS, MISSA, MO, MUHW, NCU, NLU, NY, TENN, TROY, US, USCH, VDB. The SERNEC portal (sernecportal.org) provided access to a number of the above herbaria. The Edward C. Swab Fund for Floristic Botany of the University of North Carolina Herbarium provided support. For taxonomic viewpoints and discussions, and review of earlier drafts, we are indebted to Loran Anderson, Edwin Bridges, Wes Knapp, Steve Leonard, Michael MacRoberts, Will McDearman, Wayne Morris, Milo Pyne, and Wendy Zomlefer. Reviews by Wendy Zomlefer, Milo Pyne, and Roger McCoy significantly improved the manuscript.

\section{REFERENCES}

ANDERSON, L.C. 1995. Noteworthy plants from north Florida. VI. Sida 16:581-587.

CARTER, R., W.W. BAKER, \& M.W. MorRIS. 2009. Contributions to the flora of Georgia, U.S.A. Vulpia 8:1-54.

Chapman, A.W. 1897. Flora of the southern United States. Third edition. American Book Co., New York, U.S.A.

Chester, E.W., B.E. Wofford, \& R. KRal. 1993. Atlas of Tennessee Vascular Plants, vol. 1. Misc. Pub. No. 9, Center for Field Biology, Austin Peay State University, Clarksville, Tennessee, U.S.A.

CoRReLL, D.S. \& M.C. Johnston. 1970. Manual of the vascular plants of Texas. Contr. Texas Research Found., Vol. 6. University of Texas at Dallas, Renner, Texas, U.S.A.

DE Quieroz, K. 2007. Species concepts and species delineation. Syst. Biol. 56:879-886

DigGs, G.M., JR., B.L. LIPSCOMB, M.D. ReED, \& R.J. O'KenNon. 2006. Illustrated flora of east Texas. Volume 1. Bot. Res. Inst. Texas, Fort Worth, U.S.A.

FernaLD, M.L. 1950. Gray's manual of botany. Eighth ed. American Book Co., New York.

GLEASON, H.A. 1952. The new Britton \& Brown illustrated flora of the northeastern United States and adjacent Canada. 3 vols. New York Bot. Gard., Bronx, New York, U.S.A.

GrAY, A. 1837. Melanthacearum Americae septentrionalis revisio. Ann. Lyceum Nat. Hist. New York 4:105-140.

Knapp, W.M., R.F.C. Naczi, W.D. Longbottom, C.A. Davis, W.A. McAvoy, C.T. Frye, J.W. HarRison, \& P. Stango, III. 2011. Floristic discoveries in Delaware, Maryland, and Virginia. Phytoneuron 2011-64:1-26.

MacRoberts, M.H., B.R. MacRoberTs, \& L.S. JaCkSON. 1999. The status of Zigadenus (Liliaceae) in the West Gulf Coastal Plain. Draft manuscript.

MACRoBerTS, M.H., B.R. MACRoBERTS, \& L.S. JACKSON. 2002. Floristics and management of pitcher plant bogs in northern Natchitoches and Winn parishes, Louisiana. Proc. Louisiana Acad. Sci. 64:14-21.

McDeARMAN, W.W. 1984. Systematics of Zigadenus densus and Z. leimanthoides and phylogenetic implications of breeding systems in the Veratreae. A.S.B. Bull. 31:71 (abstract).

McDearman, W.W. 1994 (17 Aug). Letter to L. Anderson at Florida State University, Tallahassee, Florida, U.S.A.

MorRIS, M.W. 2012. Stenanthium leimanthoides (Melanthiaceae) and Nestronia umbellula (Santalaceae) in Alabama. Castanea 77:375-380.

PYNE, M. 2000. Biogeographic study of The Barrens of the Southeastern Highland Rim of Tennessee. Report prepared by the Association for Biodiversity Information for Arnold Engineering Development Center, Arnold Air Force Base, Tennessee.

RADFORD, A.E., H.E. AHLES, \& C.R. BelL. 1968. Manual of the vascular flora of the Carolinas. University of North Carolina Press, Chapel Hill, U.S.A.

SchwarTZ, F.C. 2002. Zigadenus. Flora of North America North of Mexico. Vol. 26, Magnoliophyta: Liliidae: Liliales and Orchidales. Oxford University Press, New York.

SinghuRst, J.R., J.C. CATHY, D. Prochaska, H. HAUCKE, G.C. KROH, \& W.C. Holmes. 2003. The vascular flora of Gus Engeling Wildlife Management Area, Anderson County, Texas. S.E. Naturalist 2:347-368.

SMALL, J.K. 1933. Manual of the southeastern flora. Privately printed.

SORRIE, B.A. \& A.S. WeAKLEY. 2001. Coastal plain vascular plant endemics: phytogeographic patterns. Castanea 66:50-82.

Tennessee Flora Committee. 2015. Guide to the Vascular Plants of Tennessee. Univ. Tenn. Press, Knoxville, Tennessee, U.S.A.

Zomlefer, W.B. \& W.S. JudD. 2002. Resurrection of segregates of the polyphyletic genus Zigadenus s.I. (Liliales: Melanthiaceae) and resulting new combinations. Novon 12:299-308. 